\title{
Unprecedented changes in mollusc assemblages of the littoral zone in the two largest peri-Alpine French lakes since the last $\mathbf{4 5 0 0}$ years
}

\author{
Jacques MOUTHON,$^{* *}$ Michel MAGNY2 \\ ${ }^{1}$ Irstea, UR MALY, 5 rue de la Doua, 69100 Villeurbanne, France; ${ }^{2}$ Laboratoire de Chrono-Environnement, UMR 6249 du CNRS, \\ UFR des Sciences et Techniques, 16 route de Gray, 25030 Besançon, France \\ *Corresponding author: jacques.mouthon@irstea.fr
}

\begin{abstract}
This paper presents changes in mollusc assemblages in the two largest peri-Alpine French lakes, i.e. Lakes Bourget and Annecy, in eastern France during the late Holocene. It is based on new mollusc data obtained in Lake Bourget: i) from three sediment cores spanning the late Holocene period; and ii) from modern samples taken around 1930 and in 2001. These new results are compared with those obtained from the neighbouring Lake Annecy and published in a previous paper. Results show that the modern period is characterised by unprecedented changes in the mollusc assemblages in Lakes Bourget and Annecy over the last 4500 years. The main drivers of the observed changes may be related to: $i)$ the recent arrival of native and exotic species; ii) the considerable regression of lacustrine macrophytes following increased anthropic pressure on these ecosystems from the 1940s onwards; and iii) modifications of the nature and quality of the fine littoral sediments of Lake Bourget, probably linked to the regulation of its water level. In addition, the arrival of new species has led to the creation of no-analogue communities, i.e. which consist of species that are extant today, but in combinations not found until now. As a result, a return to the initial state in terms of community structures is thus difficult to envisage. On the contrary, re-establishing the dominance of charophytes and thus the dominance of gastropods, characteristic of the littoral malacocenoses of the Holocene, is a conceivable objective. Nonetheless, the persistence and extension of the period of hypoxic hypolimnion associated with warmer winters expected in the northern hemisphere could affect the recovery process negatively.
\end{abstract}

Key words: molluscs, Lakes Bourget Annecy, changes, modern period, Late Holocene.

Received: June 2013. Accepted: September 2013.

\section{INTRODUCTION}

Lakes are considered to be ecosystems of particular interest for analysing past and future environmental impacts (Williamson et al., 2008; 2009; Adrian et al., 2009). Their sediments contain archives of variations occurring over different periods of time within a catchment at regional scale (e.g., inputs of nutrients, contamination by heavy metals and anthropogenic chemical substances) and at continental scale (climate change). Paleoecological and paleoenvironmental records have been used to reconstruct past environmental and climate change, and more recently to establish reference conditions (e.g., before significant anthropogenic influence) and the good status of the European Water framework Directive (Europe Union, 2000) which sets ambitious perspectives for the restoration and rehabilitation of damaged ecosystems (Jackson and Hobbs, 2009; Bennion et al., 2011). The difference between these two states (e.g., between the reference and present-day states) permits measuring the impact of human activities. Consequently, multi-proxy palaeolimnological analysis of the sediments of the deep zone of peri-Alpine (Bourget and Annecy) and Alpine (Moaralmsee and Oberer Landschitsee) lakes has made it possible to trace the evolution of both trophic states and anoxia in the hypolimnion (Giguet-Covex et al., 2010; Millet et al., 2010; Frossard, 2013) and the impact of the present-day climate warming on invertebrate communities (Luoto and Nevalainen, 2012; Nevalainen and Luoto, 2012).

However, the littoral zone is colonised by a far richer fauna than the deep zone and the life history traits of its species are more diversified. Therefore the organisms abundant in this zone, such as molluscs, can be used to analyse the consequences of other negative aspects of anthropic pressure (destruction of habitats, reduction of lacustrine macrophytes, changes in community structure, declining biodiversity) and of the arrival of alien species. To this end analyses were performed i) on mollusc data of Lakes Annecy and Bourget taken from several cores collected in the framework of archaeological investigations (Marguet, 1999) and the Climasilac programme (Oldfield and Berthier, 2001); ii) on an inventory established in the 1930s (Favre, 1940) when Lake Bourget had been invaded for several years by the alien species Dreissena polymorpha (Le Roux, 1928); and iii) on samples from the littoral zones of these lakes.

Thus, this paper presents changes in mollusc assemblages in the two largest peri-Alpine French lakes, i.e. Lakes Bourget and Annecy, in eastern France during the 
late Holocene. The present study is based on new mollusc data obtained in Lake Bourget from three sediment cores spanning the late Holocene period, as well as from modern samples taken around 1930 by Favre (1940) and by J. Mouthon in 2001. These new results are compared with those obtained from the neighbouring Lake Annecy and published in a previous paper (Mouthon and Magny, 2004).

\section{METHODS}

\section{Study sites}

Lake Bourget $\left(45^{\circ} 45^{\prime} \mathrm{N}-5^{\circ} 55^{\prime} \mathrm{E}\right)$ is a $18-\mathrm{km}$-long narrow and over-deepened basin of glacial origin. It is located at an altitude of $231.5 \mathrm{~m}$ in the northern French Pre-Alps (Fig. 1). The lake area is ca. $44.6 \mathrm{~km}^{2}$ and the maximum depth reaches $150 \mathrm{~m}$. Its catchment area covers $550 \mathrm{~km}^{2}$ with a maximal elevation at $1845 \mathrm{~m}$ asl. However, during major flooding events of the Rhone River (a catchment of $4000 \mathrm{~km}^{2}$ culminating at $4807 \mathrm{~m}$ asl), the outlet of the lake via the Savière canal functioned as an inlet and sometimes provoked catastrophic flooding before recent arrangements to regulate lake-level fluctuations (Chapron et al., 2005). The lake is fed by seasonal

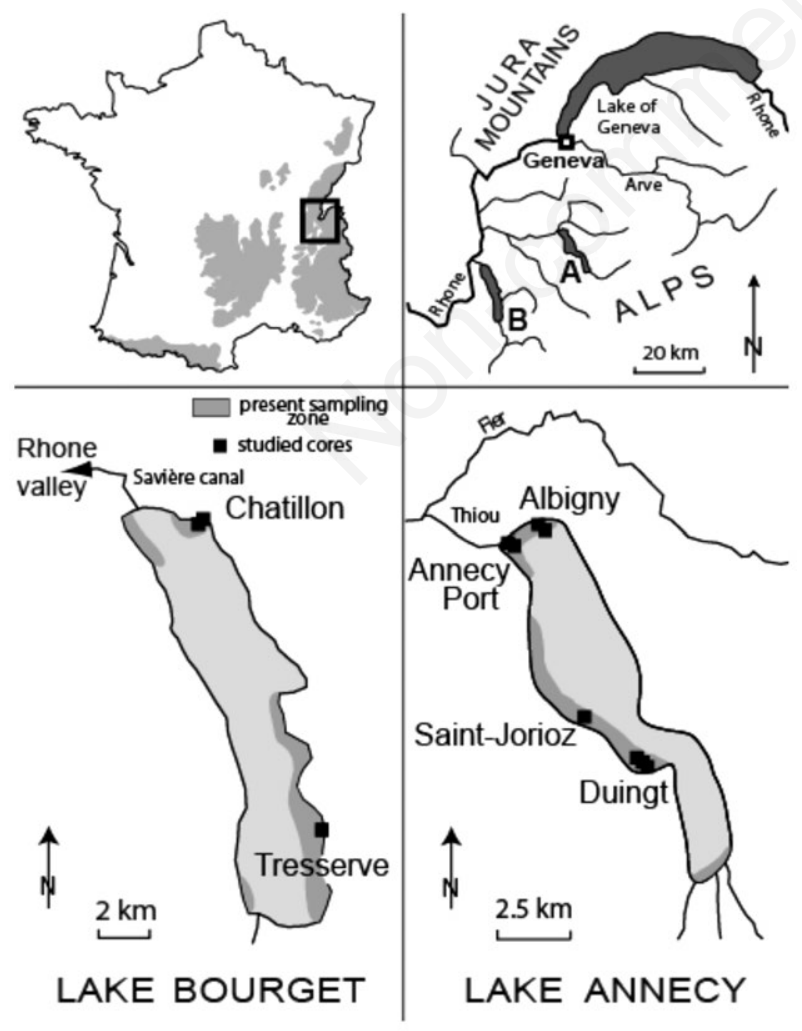

Fig. 1. Geographical location of Lakes Annecy and Bourget. Location of the sediment cores (black squares) and area of present-day mollusc sampling (dark grey shaded areas). rain and snow melting. At present, the lake is considered as meromictic with complete turnover occurring only during cold winters (Vinçon-Leite et al., 1995). Since 1982, following the hydraulic development on the Upper Rhone, natural fluctuations in the water levels have been considerably reduced and the present water-level is artificially maintained between 231.2 and $231.5 \mathrm{~m}$ asl. The climate of the area can be defined as temperate. The mean annual temperature is ca. $12^{\circ} \mathrm{C}$, in the coldest month $3^{\circ} \mathrm{C}$ and $21^{\circ} \mathrm{C}$ in the warmest. Annual precipitation reaches ca. $1150 \mathrm{~mm}$. The Holocene deposits of Lake Bourget are mainly composed of sand (detrital input from the catchment area) and authigenic carbonate lake marl.

Lake Annecy (42 $52^{\prime} \mathrm{N}-6^{\circ} 09^{\prime} \mathrm{E}$ ) is located ca. $25 \mathrm{~km}$ away from Lake Bourget, to the east (Fig. 1). Its catchment area reaches ca. $251 \mathrm{~km}^{2}$ and there is no glaciers or permanent snow in the present-day drainage basin (summits generally below $3000 \mathrm{~m}$ asl). The lake monomictic is fed by seasonal rain and snow-melting. The surface covers $26.5 \mathrm{~km}^{2}$ and the present water-level is artificially maintained at $446.6 \mathrm{~m}$ asl. The climate conditions at Lake Annecy are close to those of Lake Bourget; the mean annual temperature at Annecy is ca. $10^{\circ} \mathrm{C}$, in the coldest month $-1.5^{\circ} \mathrm{C}$ and in the warmest $19^{\circ} \mathrm{C}$, while annual precipitation reaches $1200 \mathrm{~mm}$.

Lakes Bourget and Annecy are considered as having been oligotrophic up the 1930s (Le Roux, 1908; Hubault, 1943). Afterwards the first signs of eutrophication appeared and the quality of their waters deteriorated up the 1970s (Annecy) and 1980s (Bourget), when different civil structures were commissioned (waste water treatment plants, wastewater drains), drastically reducing the inflow of waste water. Now, Lake Annecy has returned to its former oligotrophic state, while Lake Bourget is meso-oligotrophic (Domaizon et al., 2012; Jacquet et al., 2012).

The Holocene deposits of Lakes Bourget and Annecy are mainly composed of sand (detrital input from the catchment area) and authigenic carbonate lake marl.

\section{Field work and sampling}

- Fossil data. Three sediment cores were taken from the littoral zone of Lake Bourget in lake-shore archaeological sites (Fig. 1), i.e. two at Tresserve on the south-eastern shore of the lake (Magny et al., 2009) and one at Chatillon on the north-eastern shore (Magny et al., 2012), using a Russian GIK type boring system and PVC tubes driven manually into the sediment. The advantage of these two methods is that they do not disturb deposits. Contiguous samples for mollusc analysis were taken at $5 \mathrm{~cm}$ intervals in each studied core.

- Favre's data (1940). The molluscs of Lake Bourget were sampled using a triangular drag-net $(36 \times 36 \mathrm{~cm}$, mesh size $800 \mu \mathrm{m})$; all the samplings were performed in the same way. The live individuals of each sample 
were identified in terms of species and counted. However, only the relative abundances (\%) of the species were available. Those of Unionidae and species living on rocks and large stones were estimated only by guessing. The sampling dates were not given, but as Favre started his work in 1935, it is reasonable to assume that most of the samplings ( 76 from 0 to $10 \mathrm{~m}$ depth) were performed before this date.

- Present data. The molluscs of sediment habitats of the littoral zone (0-3 m water-depth) were collected in summer 2001 (Bourget) and in summers 2000, 2001 and 2002 (Annecy) (Fig. 1). From 0 to $1.5 \mathrm{~m}$, sampling was carried out using a rectangular hand-net $(25 \times 18 \mathrm{~cm}$, mesh size $500 \mu \mathrm{m})$, with a surface area from 1 to $2 \mathrm{~m}^{2}$ sampled according to site; from 1.5 to $3 \mathrm{~m}$, a Van Veen grab (surface: $250 \mathrm{~cm}^{2}$ ) was used. Samples from stony habitats were collected by Scuba divers using a $1 / 4 \mathrm{~m}^{2}$ sample frame. A total of 29 sites were prospected in Bourget vs 33 in Annecy. The abundance of present-day species at each site is expressed per square metre.

\section{Laboratory methods}

The fossil and actual samples were sieved at $500 \mu \mathrm{m}$ then shells were sorted and identified by using a binocular microscope. For fossil molluscs, the abundance of different species of gastropods was obtained by considering each apex as an individual. For the bivalves, as samples are composed of right and left valves and complete individuals, species abundance was calculated by adding half the number of valves to the total of complete individuals. The mollusc assemblages from the archaeological layers were not taken into account, since they were liable to be biased by human impact. The average abundance of the species of each successive pollen zone (Younger Atlantic, Subboreal and Subatlantic) was calculated for each lake. Finally, the numbers of fossil and modern species were transformed into percentages for comparison. The taxonomic identification of the mollusc species was carried out by using keys published by Ellis (1978) and Glöer and Meier-Brook (2003).

\section{Statistical analysis}

We used a principal component analysis performed on mollusc abundance data (\%) in order to evaluate changes in community composition and structure. This statistical analyse was extracted from the Statistica package (Statsoft, version 9.0). The results from Lake Annecy and used below for comparison with those from Lake Bourget have been obtained from similar types of sites (i.e., sediment cores and samples in littoral zone) and using the same methods as those used for the present study (Mouthon and Magny, 2004).

\section{Chronology}

In addition to tree-ring dates provided prehistoric wooden posts found in archaeological layers, two methods were used for absolute dating of the sediment sequences studied as follows:

- Radiocarbon dating. The material used was the remains of plants of terrestrial origin (to avoid the hardwater effect) and wooden pieces accumulated by prehistoric man on archaeological lake-shore sites. Over the past 10 years, the development of the AMS technique for dating small amounts of plant macrofossils has made it possible to date poorly organic sediment layers and reduce the standard deviation of radiocarbon dating.

- Regional pollen stratigraphy. The history of the Holocene vegetation in the Northern French Pre-Alps is well-known due to the pollen analysis of sediment sequences taken from Lakes Bourget and Annecy as well as from many radiocarbon-dated regional sites (de Beaulieu et al., 1994; David et al., 2001; Magny et al., 2009).

\section{RESULTS}

\section{Core description and chronology}

Fig. 2 presents the lithological profiles and chronological data for the cores taken from Tresserve and Chatillon in Lake Bourget. Since limestone was predominant in the catchment area, the lake sediments were mainly composed of yellow calcareous lake marl, consisting of carbonate concretions of biochemical origin from bacterial (Cyanophyceae) and algal (Characeae) activity and from phenomena associated with the photosynthetic activity of aquatic vegetation (Phragmites, Scirpus, Nuphar). The texture showed silts to be generally predominant (ca. 50-60\%); coarser deposits indicate former near-shore areas (shallow water and higher hydrodynamism) characterised by the development of oncolites and the inclusion of organic macroremains inherited from the littoral vegetation.

Regarding the chronology, the sediment cores taken from Tresserve and Chatillon included anthropogenic layers interbedded in lacustrine deposits. These browncoloured organic layers were composed of vegetal remains accumulated by humans on Bronze Age lakedwelling sites. Wooden posts used by prehistoric people for dwelling construction are well-preserved in these lakeshore archaeological sites and can provide precise dendrochronological dates (Marguet, 1999). Moreover, referring to the regional pollen stratigraphy, different successive regional pollen zones have been distinguished from pollen analysis and radiocarbon dated. At the transition between the mid- and the late Holocene, the Younger Atlantic was characterised by the domination of Abies. During the late Holocene, the Subboreal pollen 
zone (from ca. 3600 to ca. 800 BC) was characterised by Abies and Fagus, and the Subatlantic pollen zone (after ca. $800 \mathrm{BC}$ ) by the immigration of Carpinus and the cultivation of Juglans (de Beaulieu et al., 1994).

\section{Mollusc data}

A total of 103,608 individuals were collected when sampling the current littoral fauna of Lakes Bourget and Annecy (64,599 vs 39,009, respectively) and 76,351 shells were extracted from the different cores $(14,780 \mathrm{vs} 61,571$, respectively). Since the distinction between the fossil individuals of Radix balthica and R. auricularia from Lake Bourget was uncertain, their shells were grouped in the genus Radix (Tab. 1). However, these species were present during the 1930s in Lake Bourget (Favre, 1940) and they belong to the present fauna of both lakes.

In the Subboreal and Subatlantic deposits of Lake Bourget 17 and 21 taxa were identified vs 25 in the 1930s and 27 at present (Fig. 3). Gastropods represented from 81.8 to $86.3 \%$ of populations at the end of the Holocene; however, those of the contemporary period
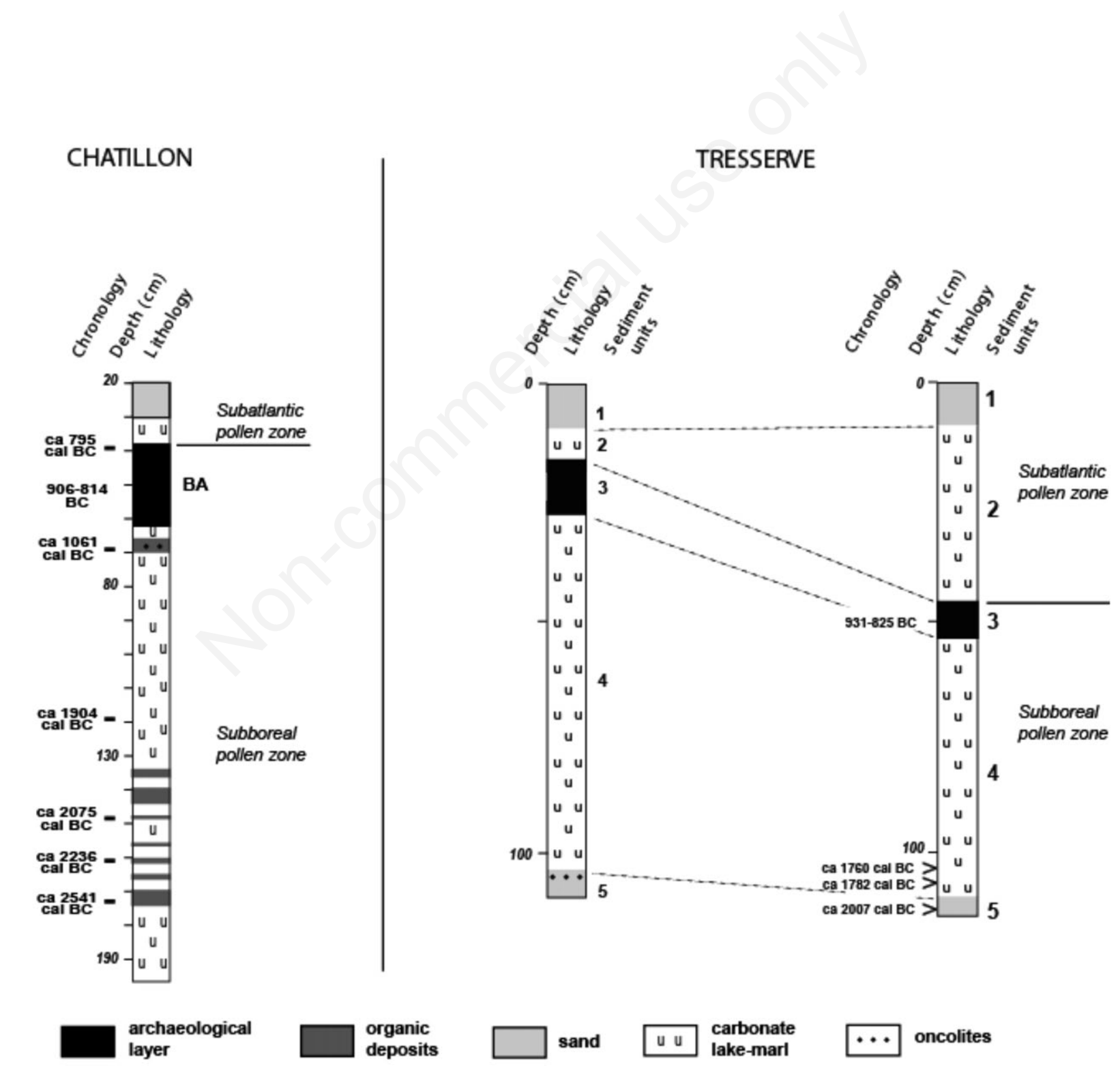

Fig. 2. Lithological profiles, pollen zones and chronology of sediment cores from Chatillon and Tresserve (Lake Bourget). Radiocarbon and tree ring ages are expressed in cal. BC (calendar years Before Christ) and in BC (years Before Christ), respectively. 
are dominated by bivalves which made up $69.7 \%$ of the populations of the 1930 s (including $45.6 \%$ for $D$. polymorpha) and $83.8 \%$ of current populations (including $77.6 \%$ for Sphaeriidae). In Lake Annecy the number of taxa identified from the Younger Atlantic to the Subatlantic pollen zones ranged from 15 to 24. Like Lake Bourget, the populations at the end of the Holocene were dominated by gastropods (from 80 to $89.7 \%$ ), though today by bivalves $(64.7 \%$ including $61.7 \%$ for Sphaeriidae) (Mouthon and Magny, 2004).

\section{Comparison of fossil, 1930s and present molluse communities}

A principal component analysis was performed on quantitative data (in percentage) from Lakes Bourget and Annecy to examine temporal changes in mollusc community structure (Fig. 4). Unionidae, whose adult shell size is large $(>75-100 \mathrm{~mm})$, were excluded from the analysis as they were not found in the core samples, probably due to the small surface areas sampled. The two first axes accounted for $62.8 \%$ of the total mollusc data inertia $(\mathrm{F} 1=37.9, \mathrm{~F} 2=24.9 \%$, respectively). The structures of fossil mollusc assemblages at the end of the Holocene in the two lakes (positive scores on axis 1) were close and varied
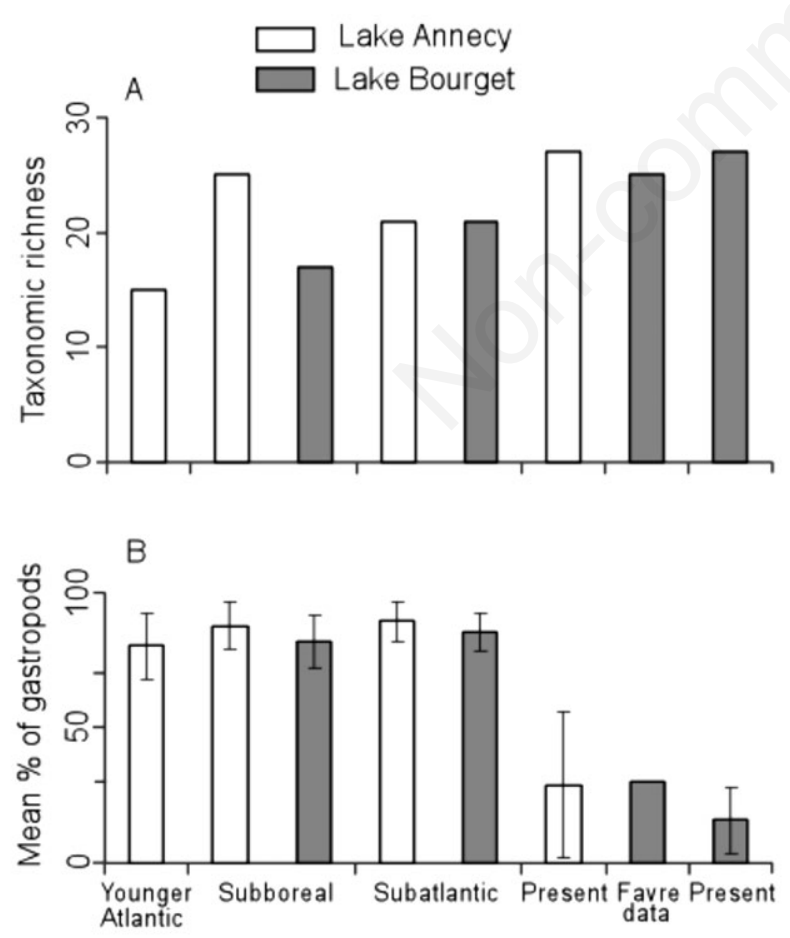

Fig. 3. Taxonomic richness (A) and mean percentage of gastropods (B) during the Late Holocene and the modern period in the littoral zone of Lakes Bourget and Annecy. Vertical bars are standard errors. little during the different periods (Fig. 4A). On the contrary, the structures of contemporary populations (negative scores on axis 1) are very far from those of the Late Holocene and different from each other.

The mollusc populations of the two lakes were dominated by gastropods (Valvata piscinalis, V. cristata, Bithynia tentaculata, Radix sp., Planorbis carinatus) while the bivalves were mainly represented by P. nitidum (Fig. 4B). The malacocenoses of Lake Bourget of the 1930s were dominated by the alien $D$. polymorpha (45.6\% of populations), but $V$. piscinalis, Pisidium moitessiarianum and Theodoxus fluviatilis were also well represented (11.4, 7.8 and $7.1 \%$, respectively). Between the 1930s and 2001 we observed a fall in the percentage of gastropods and a strong increase in that of Sphaeriidae (30.0 vs $15.8 \%$ and 18.4 vs $77.6 \%$ of populations, respectively), the appearance of the exotic Potamopyrgus antipodarum and Phy-
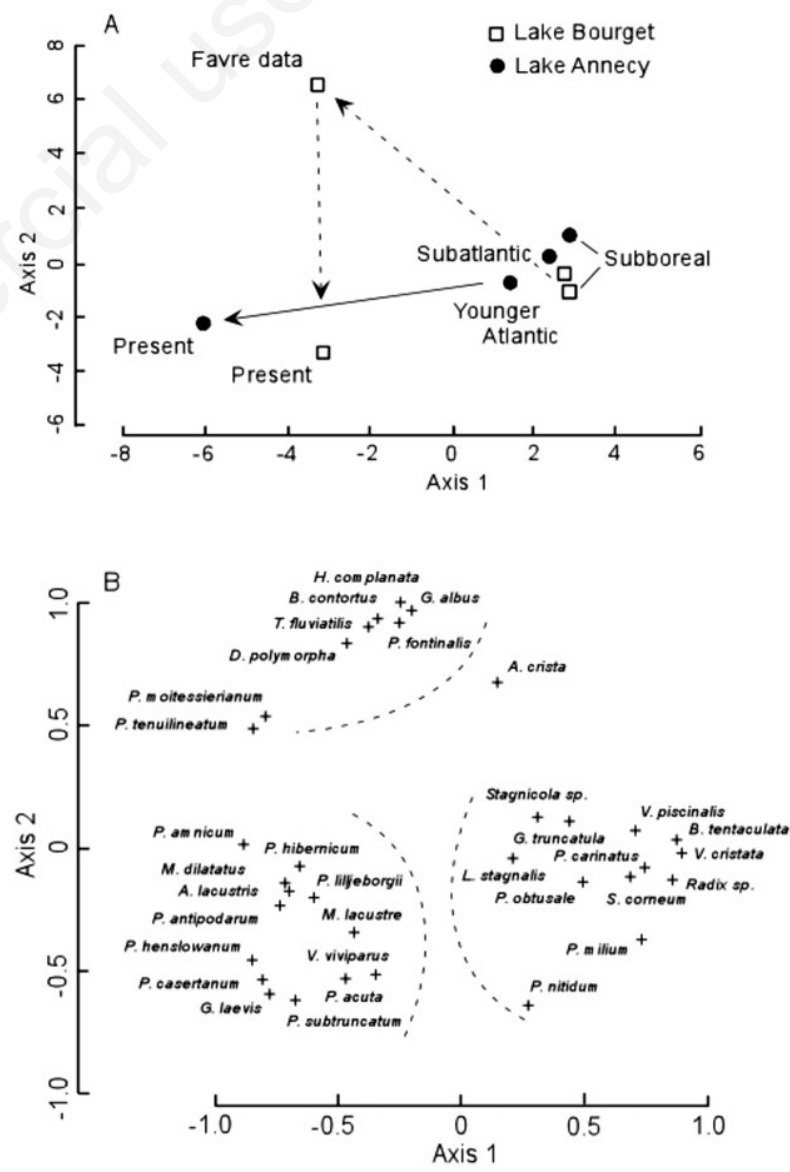

Fig. 4. Results of the principal component analysis performed on mollusc data (in percentage) in the littoral zone of Lakes Bourget and Annecy. Scores of the different periods (A) and taxa (B) on the two first axes. Dashed lines indicate taxa preferentially associated to the Late Holocene, the 1930s and the present-day communities. 
sella acuta, Viviparus viviparus, Lymnaea stagnalis, Gyraulus laevis, Sphaerium corneum, Pisidium milium and, finally, the disappearance from the inventory of 2001 of Physa fontinalis, Armiger crista, Bathyomphalus contortus, Anodonta anatina and Potomida littoralis (Tab. 1).

The difference between the population structures of Lakes Bourget and Annecy is greater today than during the late Holocene. The species presently most abundant (14 molluscs with $\%>1$ ) are common to both lakes but only five of them are better represented in Lake Annecy, including $P$. antipodarum, Pisidium hibernicum and $P$. moitessierianum which represent $32.7,9.8$ and $7.8 \%$ of its populations, respectively (Tab. 1). Furthermore, T. fluviatilis, $V$. viviparus, $L$. stagnalis and $P$. carinatus were only identified in Lake Bourget, while the exotic Menetus dilatatus, A. crista, Acroloxus lacustris, Pisidium lilljeborgii was identified only in Lake Annecy.

\section{DISCUSSION}

Data collected from sediment cores and samples taken in the 1930s by Favre and more recently in the 2000s highlight the rapid changes occurring in the mollusc com-

Tab. 1. Mean abundance of mollusc taxa (\%) during the Late Holocene and the contemporary period in the littoral zone of Lakes Annecy and Bourget.

\begin{tabular}{|c|c|c|c|c|c|c|c|c|}
\hline & \multirow{2}{*}{$\begin{array}{c}\text { Younger Atlantic } \\
(4700-3600 \text { BC) } \\
\text { Annecy }\end{array}$} & \multicolumn{2}{|c|}{$\begin{array}{c}\text { Subboreal } \\
(3600-800 \mathrm{BC})\end{array}$} & \multicolumn{2}{|c|}{$\begin{array}{c}\text { Subatlantic } \\
\text { (after } 800 \mathrm{BC})\end{array}$} & \multicolumn{3}{|c|}{ Contemporary period } \\
\hline & & Annecy & Bourget & Annecy & Bourget & Annecy & Favre's data & Bourget \\
\hline \multicolumn{9}{|l|}{ Gastropods } \\
\hline Bithynia tentaculata & 12.1 & 26.6 & 17.8 & 25.9 & 14.4 & 0.6 & 1.4 & 1.0 \\
\hline Potamopyrgus antipodarum & - & - & - & - & - & 32.7 & - & 2.4 \\
\hline Theodoxus fluviatilis & - & - & - & - & - & - & 7.1 & 0.03 \\
\hline Valvata cristata & 12.1 & 24.9 & 15.1 & 28.0 & 23.4 & 0.2 & 0.7 & 0.07 \\
\hline$V$. piscinalis & 43.9 & 24.2 & 20.3 & 17.8 & 18.8 & 1.2 & 11.4 & 5.9 \\
\hline Viviparus viviparus & - & - & - & - & - & - & - & 0.01 \\
\hline Radix sp. & 9.6 & 8.3 & 19.4 & 12.4 & 18.8 & 0.05 & 3.5 & 4.8 \\
\hline Lymnaea stagnalis & - & 0.05 & - & - & - & - & - & 0.02 \\
\hline Stagnicola sp. & - & 0.02 & - & - & - & - & - & - \\
\hline Galba truncatula & - & 0.1 & - & 0.09 & - & - & - & - \\
\hline Physa fontinalis & 0.01 & 0.05 & 0.01 & 0.01 & 0.05 & - & 0.7 & - \\
\hline Physella acuta & - & - & - & - & - & 0.2 & - & 1.2 \\
\hline Acroloxus lacustris & - & - & - & - & - & $>0.01$ & - & - \\
\hline Armiger crista & - & 2.0 & & 0.5 & 0.06 & $>0.01$ & 1.4 & - \\
\hline Bathyomphalus contortus & - & 0.04 & & 0.02 & & & 0.7 & - \\
\hline Gyraulus albus & 0.07 & 0.3 & 0.2 & 0.3 & 0.2 & 0.02 & 1.7 & $>0.01$ \\
\hline G. laevis & - & - & - & - & - & 0.2 & - & 0.3 \\
\hline Hippeutis complanata & - & 0.07 & & 0.08 & 0.2 & 0.01 & 0.7 & 0.02 \\
\hline Planorbis carinatus & 2.3 & 3.1 & 9.0 & 3.9 & 10.6 & - & 0.7 & 0.10 \\
\hline Menetus dilatatus & - & - & - & - & - & 0.01 & - & - \\
\hline \multicolumn{9}{|l|}{ Bivalves } \\
\hline Dreissena polymorpha & - & - & - & - & - & 2.9 & 45.6 & 6.2 \\
\hline Anodonta cygnea & - & - & - & - & - & 0.02 & 2.9 & $>0.01$ \\
\hline Anodonta anatina & - & - & - & - & - & - & 0.7 & - \\
\hline Potomida littoralis & - & - & - & - & - & - & 0.7 & - \\
\hline Unio pictorum & - & - & - & - & - & 0.01 & 1.4 & 0.07 \\
\hline Musculium lacustre & - & 0.03 & 0.02 & - & 0.2 & 0.05 & 0.7 & 4.1 \\
\hline Sphaerium corneum & 0.02 & 0.3 & 0.2 & 0.5 & 0.3 & 0.01 & - & 0.08 \\
\hline Pisidium amnicum & - & 0.04 & 0.02 & 0.2 & 0.01 & 2.1 & 0.7 & 0.3 \\
\hline P. casertanum & 0.06 & 0.1 & - & 0.3 & 0.2 & 6.0 & 0.7 & 8.7 \\
\hline P. conventus & - & 0.01 & - & - & - & - & - & - \\
\hline P. henslowanum & 0.01 & 0.01 & - & 0.2 & 0.08 & 10.5 & 2.9 & 15.5 \\
\hline P. hibernicum & 1.6 & 1.1 & 1.5 & 0.5 & 0.5 & 9.8 & 1.4 & 0.06 \\
\hline P. lilljeborgii & 0.08 & 0.07 & 0.03 & 0.2 & 0.09 & 0.8 & - & - \\
\hline P. milium & 1.2 & 0.9 & 2.7 & 1.4 & 1.7 & 0.4 & - & 0.7 \\
\hline P. moitessierianum & - & - & - & - & - & 7.8 & 7.8 & 0.2 \\
\hline P. obtusale & - & - & 0.6 & - & 0.6 & - & - & - \\
\hline P. nitidum & 16.6 & 6.4 & 11.3 & 6.5 & 9.0 & 3.3 & 2.9 & 16.5 \\
\hline P. subtruncatum & 0.4 & 1.4 & 1.8 & 1.0 & 0.9 & 19.3 & 0.01 & 31.0 \\
\hline P. tenuilineatum & - & 0.02 & 0.03 & 0.2 & 0.2 & 1.6 & 1.4 & 0.35 \\
\hline Actual totals & 16,124 & 22,192 & 5126 & 23,255 & 9654 & 39,009 & - & 64,599 \\
\hline
\end{tabular}


munity during the last hundred years in comparison with their relative stability during the late Holocene.

During the late Holocene, the structures of mollusc populations of Lakes Bourget and Annecy remained very similar. In spite of the smaller number of core samples extracted from the littoral zone of Lake Bourget ( $3 v s 8$ at Annecy), the relative abundances of the species were close to those obtained by Favre (1940), based on the sampling performed at the top of lacustrine chalk using a drag-net (twelve points from 6 to $20 \mathrm{~m}$ depth) and can therefore be considered as representative of the fossil assemblages of this lake. Globally, populations analogous to those in Lakes Bourget and Annecy can be found in the Holocene chalk deposits of a large number of lakes in Switzerland (Favre, 1935, 1940; Magny et al., 2005), France (Clerc et al., 1989; Magny and Mouthon, 1990; Mouthon and Vilain, 1990; Magny et al. 1995; Mouthon and Magny, 2004), Germany (Griffiths et al., 1994), and the United Kingdom (Walker et al., 1993).

Submerged macrophytes play a structural role for macro-invertebrates, increase habitat diversity and the quantity of available food (epiphyton), provide shelter against predators and serve as a substrate for oviposition (Jeppesen et al., 1998, and references herein). Consequently, the specific richness and density of gastropods is higher in vegetated habitats than in non-vegetated littoral ones (Brönmark, 1985; Lodge, 1985; Lodge and Kelly, 1985; Lodge et al., 1987; Brown and Lodge, 1993; Cronin et al., 2006). In lacustrine ecosystems, Characeae, of which certain species are capable of overwintering, provide a particularly favourable habitat for gastropods (Peyrera-Ramos, 1981; Van den Berg et al., 1997; Ayres et al., 2008). As indicated by the presence of numerous calcified remains of Charophytes in the samples of lacustrine chalk, these algae were present in abundance in the littoral and sublittoral zones of Lakes Bourget, Annecy and Geneva (Favre, 1935, 1940; Hubault, 1943). Conversely, dense Chara meadows create anoxic conditions within sediments (Blindow, 1992; Van den Berg, 1997) detrimental to sphaeriid bivalves. The abundance of Charophytes in these ecosystems therefore appears to be an essential determinant for the structure of their mollusc communities and that of many lakes during the Holocene.

The first signs of eutrophication appeared from 1940s onward (Hubault, 1943; Giguet-Covex et al., 2010; Millet et al., 2010; Frossard et al., in press) and anthropic pressure (urbanisation of banks, recreational activities, bank erosion, regulated water levels, etc.) increased around Lakes Bourget and Annecy, causing their lacustrine macrophytes to regress considerably (Blake, 1992) and thus their gastropod populations. However, the reduction of the surface area occupied by macrophytes has greatly favoured sphaeriid bivalves which inhabit fine sediment and constitute, between 0 and $3 \mathrm{~m}$ depth, 84.2 and $71.1 \%$ of their populations, re- spectively. Below $3 \mathrm{~m}$ depth, Sphaeriidae still represent the majority of the populations both up and downstream of Lake Bourget, 63.0 and $99.3 \%$ at $5 \mathrm{~m}$ depth, and 98.8 and $76.8 \%$ at $10 \mathrm{~m}$ depth, respectively (CEMAGREF, 1989). On the other hand, in Lake Annecy, where Charophytes are still abundant locally between 4 and $6 \mathrm{~m}$ depth, gastropods total $49.3 \%$ of the populations vs $20.6 \%$ for Sphaeriidae (Mouthon and Magny, 2004).

From a malacological point of view, Favre (1940) considered Lake Bourget as atypical in comparison to other peri-Alpine lakes such as Geneva, Annecy, Neuchatel and Bodensee. Indeed, the numbers of Pulmonates and those of most of the Sphaeriidae were very low, and the populations of lake were dominated by species (D. polymorpha, P. moitessierianum and T. fluviatilis) absent or rare in the other lakes. This was all the more surprising, as before the arrival of $D$. polymorpha, Pulmonates and Unionidae were abundant in the littoral zone of Lake Bourget (Bourguignat, 1864). The dense populations of the filter feeder $D$. polymorpha could therefore be responsible for the regression of its mollusc communities, as suggested by Favre (1940).

After the extension of this bivalve in Eastern and Western Europe and its recent introduction in North America, the consequences of its proliferation on freshwater ecosystems are now well documented. Its impact on mollusc populations generally results in a considerable fall in the density of the other filter feeders (Unionidae) and interstitial suspension feeders (Sphaeriidae) and an increase in that of small gastropods that do not compete with D. polymorpha (Schloesser and Nalepa, 1994; Karatayev et al., 1997; Ricciardi et al., 1998; Strayer, 1999; Lauer and McComish, 2001; Strayer and Malcom, 2007; Ward and Ricciardi, 2007; Higgins and Vander Zanden, 2010). According to the observations of Bourguignat (1864) and Favre (1940), Unionidae and Pulmonates in particular decreased considerably after the arrival of this invasive species before 1913-1914 (Le Roux, 1928). However, the percentage of small grazing Prosobranchs such as V. piscinalis remains high and T. fluviatilis is common everywhere in the lake (Favre, 1940). Furthermore, gastropods are globally better represented than Sphaeriidae (30 vs $18.4 \%$ of populations) although, given the mesh size $(800 \mu \mathrm{m})$ of the net used by Favre, the abundance of the smallest species $P$. moitessierianum and $P$. tenuilineatum (shell length $\sim 2 \mathrm{~mm}$ ) is somewhat underestimated. These observations strongly suggest that this bivalve acted as driver rather than passenger of the structure of mollusc communities (Mac Dougall and Turkington, 2005; Didham et al., 2005). In addition, since $D$. polymorpha and the Charophytes require large amounts of calcium to develop (Pereyra-Ramos, 1981; Mellina and Rasmussen, 1994), the dense populations of this bivalve were perhaps also responsible for the low abundance of 
these algae in Lake Bourget during the 1930s whereas they formed huge prairies in Lake Annecy (Favre, 1940; Hubault, 1943) where D. polymorpha was not observed until the 1960s (Juget, 1967). But in this lake, this bivalve does not appear to have experienced the same success as at Bourget, undoubtedly due to the less favourable thermal and trophic conditions.

Present-day mollusc assemblages in Lake Bourget can be distinguished from those of the 1930s, mainly by the reduction of $D$. polymorpha (45.6 vs 6.2\%) and a considerable increase of Sphaeriidae (77.6 vs 18.4\%). Nonetheless, $P$. moitessierianum, which was abundant in the littoral zone of the lake and frequent to $18-19 \mathrm{~m}$ depth in the 1930s (Favre, 1940) has regressed dramatically, its percentage falling from 7.8 to $0.2 \%$. Prospections performed in 1988 at depths of 5 and $10 \mathrm{~m}$ have shown that only a few individuals were present at the upstream end of the lake and that none were present at its downstream end (CEMAGREF, 1989). What is more, the species of Pisidium that were represented in the 1930s by their ponderous forms (thick shell and hinge) between 0 and $3 \mathrm{~m}$ depth have been replaced by typical forms. These ponderous varieties that inhabit the warm, calcium-rich waters of lakes at low altitude and the potamon of rivers (MeierBrook, 1975; Mouthon, 1999) become abundant again only at $5 \mathrm{~m}$ depth (CEMAGREF, 1989). The replacement of $P$. moitessierianum, which is sensitive to organic matter, by Pisidium subtruncatum, $P$. nitidum and $P$. henslowanum, which are more tolerant (Tab. 1) (Mouthon, 1996), and the disappearance of ponderous forms between 0 and $3 \mathrm{~m}$ depth demonstrate that the physico-chemical composition and quality of the fine sediments in which these bivalves live has changed considerably. The regulation of the level of the lake from 1980, which has substantially modified environmental conditions (Dinka et al., 2004; Furey et al., 2004) and favoured the accumulation of organic matter in the littoral zone, provides the most probable explanation for the changes observed since Favre's inventory (1940).

Physa fontinalis and P. lilljeborgii, present in Lake Bourget at the end of the Holocene, have disappeared from its current fauna, although the first of these two species was still present in the 1930s. Rare in Lake Annecy, $P$. fontinalis has been progressively replaced in these ecosystems by Physella acuta, a particularly tolerant invasive species (Mouthon, 1996). Conversely, these two lakes have been recently colonised by 7 new molluscs: 3 native species (P. moitessierianum, G. laevis, $V$. viviparus) and 4 exotic species (D. polymorpha, $P$. antipodarum, $P$. acuta, M. dilatatus) that have been joined by Corbicula fluminea since 2003. The arrival of these species, most of which prefer warm waters (Mouthon, 1999), coincides with the temperature increases observed from 1910 to 1930 (D. polymorpha and P. moitessierianum in Lake
Bourget), and then with the recent warming (http://www. zamg.ac.at/HISTALP/).

Regarding the general climatic context of the late Holocene, after the mid-Holocene climatic optimum, the last seven millennia were characterised by a trend toward cooler climatic conditions due to a decrease in orbitally-driven insolation (Berger and Loutre, 1991). Quantitative assessments suggest that this general cooling trend may have been slightly more than $1{ }^{\circ} \mathrm{C}$ in terms of summer temperature for the region studied (Heiri et al., 2004; Renssen et $a l ., 2009$ ) and that the present-day warming (although characterised by a rapid elevation of temperature) still remains below the temperature level of the mid-Holocene climatic optimum (Marcott et al., 2013). In addition, superimposed on this general cooling trend, regional palaeoclimatic records based on various proxies such as pollen, Chironomidae, lake-level fluctuations and timberline variations, show that the last seven millennia have been punctuated by successive centennial-scale climatic oscillations with variations in summer temperature by ca. $0.7-1{ }^{\circ} \mathrm{C}$ (Heiri et al., 2004; Magny et al., 2009). Thus, on millennial as well as centennial scales, the variations in climatic conditions during the late Holocene until the ongoing warming do not appear to have provoked major changes in the mollusc assemblages in Lakes Bourget and Annecy, as shown by Fig. 4, where the fossil data are grouped in a single cluster.

\section{CONCLUSIONS}

Results show that the modern period is characterised by unprecedented changes in the mollusc assemblages in Lakes Bourget and Annecy over the last 4500 years. The recent arrival of native and exotic species, the considerable regression of lacustrine macrophytes following increased anthropic pressure on these ecosystems from the 1940s onwards, and modifications of the nature and quality of the fine littoral sediments of Lake Bourget, probably linked to the regulation of its water level, count among the main drivers of the changes observed. Furthermore, the arrival of new species has led to the creation of no-analogue communities, i.e. which consist of species that are extant today, but in combinations not found until now (Williams and Jackson, 2007; Strayer, 2010). A return to the initial state in terms of community structures is thus difficult to envisage. On the contrary, re-establishing the dominance of charophytes and thus the dominance of gastropods, characteristic of the littoral malacocenoses of the Holocene, is a conceivable objective. This has been demonstrated by the return to oligotrophic and meso-oligotrophic conditions observed at Lakes Annecy and Bourget after the drastic reduction of their nutrient inputs (Domaizon et al., 2012; Jacquet et al., 2012). Nonetheless, the persistence and extension of the period of hypoxic hypolimnion associated with warmer winters expected in the northern hemisphere (IPCC, 2007) could affect the recovery process negatively. 


\section{REFERENCES}

Adrian R, O'Reilly CM, Zagarese H, Baines SB, Hessen DO, Keller W, Livingstone DM, Sommaruga R, Straile D, Van Donk E, Weyhenmeyer A, Winder M, 2009. Lakes as sentinels of climate change. Limnol. Oceanogr. 54:2283-2297.

Ayres KR, Sayer CD, Skeate ER, Perrow MR, 2008. Palaeolimnology as a tool to inform shallow lake management: an example from Upton Great Broad, Norfolk, UK. Biodivers. Conserv. 17:2153-2168.

Bennion H, Battarbee R, Sayer C, Simpson G, Davidson T, 2011. Defining reference conditions and restoration targets for lake ecosystems using palaeolimnology: a synthesis. J. Paleolimnol. 45:533-544.

Berger A, Loutre MF, 1991. Insolation values for the climate of the last 10 million of years. Quaternary Sci. Rev. 10:297-317.

Blake G, 1992. [Etude de la dégénérescence des roselières du lac d'Annecy]. [Article in French]. Rapport Syndicat Intercommunal du lac d'Annecy: 13 pp.

Blindow I, 1992. Long- and short-term dynamics of submerged macrophytes in two shallow eutrophic lakes. Freshw. Biol. 28:15-27.

Bourguignat JR, 1864. [Malacologie d'Aix-les-Bains]. [Book in Fench]. F. Savy, Paris: 128 pp.

Brönmark C, 1985. Freshwater snail diversity: effects of pond area, habitat heterogeneity and isolation. Oecologia 67:127-131.

Brown KM, Lodge DM, 1993. Gastropod abundance in vegetated habitats: the importance of specifying null models. Limnol. Oceanogr. 38:217-225.

CEMAGREF, 1989. Lac du Bourget, diagnose rapide 1988. Ronéo: 16 pp plus appendix.

Clerc J, Magny M, Mouthon J, 1989. [Histoire d'un milieu lacustre du Bas-Dauphiné: Le Grand Lemps. Etude palynologique des remplissages Tardiglaciaires et Holocènes, et mise en évidence des fluctuations lacustres à l'aide d'analyses sédimentologiques et malacologiques]. [Article in French]. Rev. Paleobiol. 8:1-19.

Chapron E, Arnaud F, Noël H, Revel M, Desmet M, Perdereau L, 2005. Rhone River flood deposits in Lake Le Bourget: a proxy for Holocene environmenta changes in the NW Alps, France. Boreas 34:404-416.

Cronin G, Lewis WM, Schiehser MA, 2006. Influence of freshwater macrophytes on the littoral ecosystem structure and function of a young Colorado Reservoir. Aquat. Bot. 85:37-43.

David F, Farjanel G, Jolly MP, 2001. Palyno- and chronostratigraphy of a long sequence from Lac d'Annecy (northern outer Alps, France). J. Paleolimnol. 25:259-269.

de Beaulieu JL, Richard H, Ruffaldi P, Clerc J, 1994. History of vegetation, climate and human action in the French Alps and the Jura over the last 15000 years. Diss. Bot. 234:253-276.

Didham RK, Tylianakis JM, Hutchinson MA, Ewers RM, Gemmell NJ, 2005. Are invasive species the drivers of ecological change? Trends Ecol. Evol. 20:470-474.

Dinka M, Àgoston-Szabò E, Berczik À, Kutrucz G, 2004. Influence of water level fluctuation on spatial dynamic of water chemistry at Lake Fertõ/Neusiedler See. Limnologica 34:48-56.

Domaizon I, Laine L, Lazzarotto J, Perga MA, Rimet F, 2012. [Suivi de la qualité des eaux du lac d'Annecy]. [Article in French]. Rapport 2011, SILA \& INRA Thonon: 92 pp.
Ellis AE, 1978. British freshwater bivalve mollusca. Academic Press Publ., London: 109 pp.

European Union, 2000. Directive 2000/60/EC of the European Parliament and of the Council of 23 October 2000 on establishing a framework for community action in the field of water policy. In: Official Journal, L327, p. 1-72.

Favre J, 1935. [Etude sur la partie occidentale du lac de Genève. II. Histoire malacologique du lac de Genève].[Article in French]. Mem. Soc. Phys. Hist. Nat. Geneve 41:295-414.

Favre J, 1940. [La faune malacologique post-glaciaire et actuelle du lac du Bourget].[Article in French]. Ann. Ecole Nat. Eaux Forets 7:295-444.

Frossard V, 2013. [Trajectoires écologiques des lacs d'Annecy et du Bourget au cours des 150 dernières années: Approche paléolimnologique par analyse des assemblages de Chironomidae (Diptera) et de leurs signatures isotopiques en carbone]. [Thesis in French]. PhD Thesis, University Franche-Comté, Besançon.

Frossard V, Millet L, Verneaux V, Jenny JP, Arnaud F, Magny M, Poulenard J, Perga ME, 2013. Chironomid assemblage reconstructions at multiple depths describe the oxygen-driven changes in a deep French lake during the last 150 years. J. Paleolimnol. 50:257-273.

Furey PC, Nordin RN, Mazumder A, 2004. Water level drawdown affects physical and biogeochemical properties of littoral sediments of a reservoir and a natural lake. Lake Reserv. Manage. 20:280-295.

Giguet-Covex C, Arnaud F, Poulenard J, Enters D, Reyss JL, Millet L, Lazzaroto J, Vidal O, 2010. Sedimentological and geochemical records of past trophic state and hypolimnetic anoxia in large, hard-water Lake Bourget, French Alps. J. Paleolimnol. 43:171-190.

Glöer P, Meier-Brook C, 2003. [Süsswassermollusken]. [Book in German]. Deutscher Jugendbund für Naturbeobachtung, Hamburg: 134 pp.

Griffiths HI, Ringwood V, Evans JG, 1994. Weichselian Lateglacial and early Holocene molluscan and ostracod sequences from lake sediments at Stellmoor, north Germany. Arch. Hydrobiol. 99:357-380.

Heiri O, Tinner W, Lotter AF, 2004. Evidence for cooler European summers during periods of changing meltwater flux to the North Atlantic. P. Natl. Acad. Sci. USA 101:1528515288.

Higgins SN, Vander Zanden MJ, 2010. What a difference a species makes: a meta-analysis of dreissenid mussels impacts on freshwater ecosystems. Ecol. Monogr. 80:179-196.

Hubault E, 1943. [Les grands lacs subalpins de Savoie sont-ils alcalitrophes?]. [Article in French]. Arch. Hydrobiol. 40:240-249.

IPCC, 2007. Intergovernmental Panel on Climate Change, Fourth Assessment Report. Available from: http://www.ipcc.ch/

Jackson ST, Hobbs RJ, 2009. Ecological restoration in the light of ecological history. Science 325:567-569.

Jacquet S, Barbet D, Cachera S, Caudron A, Colon M, Girel C, Guillard J, Hébert A, Kerrien F, Laine L, Lazzarotto J, Moille JP, Paolini G, Perga M, Perney P, Rimet F, 2012. [Suivi environnemental des eaux du lac du Bourget pour l'année 2011]. [Article in French]. INRA-CISALB: 220 pp.

Jeppesen E, Søndergaard M, Søndergaard M, Christoffersen K, 1998. The structuring role of submerged macrophytes in 
lakes. Ecological Series, vol. 131. Springer-Verlag, Berlin: $423 \mathrm{pp}$.

Juget J, 1967. [La faune benthique du Léman: modalités et déterminisme écologique des peuplements].[Thesis in French]. University of Lion.

Karatayev AY, Burlakova LE, Padilla DK, 1997. The effects of Dreissena polymorpha (Pallas) invasion on aquatic communities in eastern Europe. J. Shellfish Res. 16:187-203.

Lauer TE, McComish TS, 2001. Impact of zebra mussels (Dreissena polymorpha) on fingernail clams (Sphaeriidae) in extreme southern Lake Michigan. J. Great Lakes Res. 27:230-238.

Le Roux M, 1908. [Recherches biologiques sur le lac d'Annecy].[Article in French]. Annales de Biologie Lacustre 2:220-387.

Le Roux M, 1928. [Recherches biologiques dans les grands lacs de Savoie, Lacs du Bourget et d'Annecy]. [Book in French]. Abry et Cie, Annecy: 164 pp.

Lodge DM, 1985. Macrophyte gastropod associations: observations and experiments on macrophyte choice by gastropods. Freshwater Biol. 15:695-708.

Lodge DM, Kelly P, 1985. Habitat disturbance and the stability of freshwater gastropod populations. Oecologia 68:111-117.

Lodge DM, Brown KM, Klosiewski SP, Stein RA, Covich AP, Leather BK, Brönmark C, 1987. Distribution of freshwater snails: spatial scale and the relative importance of physicochemical and biotic factors. Am. Malacol. Bull. 5:73-84.

Luoto T, Nevalainen L, 2012. Ecological responses of aquatic invertebrates to climate change over the past $\sim 400$ years in a climatically ultra-sensible lake in the Niedere Tauern Alps (Austria). Fundam. Appl. Limnol. 181:169-181.

MacDougall AS, Turkington R, 2005. Are invasive species the drivers or passengers of change in degraded ecosystems? Ecology 86:42-55.

Marcott SA, Shakun JD, Clark PU, Mix AC, 2013. A reconstruction of regional and global temperature for the past 11300 years. Science 339:1198-1201.

Magny M, Mouthon J, 1990. [Interprétation paléolimnimétrique d'une coupe stratigraphique de la station 2 de Chalain (Jura): comparaison des approches sédimentologique et malacologique].[Article in French]. Arch. Sci. Geneve 43:99-115.

Magny M, Mouthon J, Ruffaldi P, 1995. Late Holocene level fluctuations of the lake Ilay in Jura, France: sediment and mollusc evidence and climatic implications. J. Paleolim. 13:219-229.

Magny M, Mouthon J, Richoz I, 2005. [Fluctuations du niveau du lac de Morat et du climat au cours du Néolithique].[Article in French]. Cah. Arch. Fribourgeoise 7:10-18.

Magny M, Peyron O, Gauthier E, Rouèche Y, Bordon A, Billaud Y, Chapron E, Marguet A, Pétrequin P, Vannière B, 2009. Quantitative reconstruction of climatic variations during the Bronze and early Iron ages based on pollen and lake-level data in the NW Alps, France. Quatern. Int. 200:102-110.

Magny M, Arnaud F, Billaud Y, Marguet A, 2012. Lake-level fluctuations at Lake Bourget (eastern France) around 4500$3500 \mathrm{cal}$. BP and their palaeoclimatic and archaeological implications. J. Quaternary Sci. 26:171-177.

Marguet A, 1999. [La Haute-Savoie du Néolithique à la fin de l'âge du Bronze, p. 56-57]. In: F. Bertrandy, M. Chevrier and J. Serralongue (eds.), [Carte archéologique de la Gaule
74 - La Haute-Savoie].[Book in French]. Académie des Inscriptions et Belles-Lettres et Fondation Maison des Sciences de l'Homme.

Meier-Brook C, 1975. [Der ökologische Indikatorwert mitteleuropäischer Pisidium Arten (Mollusca, Eulamellibranchiata)].[Article in German]. Eiszeitalter und Gegenwart 26:190-195.

Mellina E, Rasmussen J, 1994. Patterns in the distribution and abundance of zebra mussel (Dreissena polymorpha) in rivers and lakes in relation to substrate and other physicochemical factors. Can. J. Fish. Aquat. Sci. 51:1024-1036.

Millet L, Giguet-Covex C, Verneaux V, Druart JC, Adatte T, Arnaud F, 2010. Reconstruction of the recent history of a large deep prealpine lake (Lake Bourget, France) using subfossil chironomids, diatoms, and organic matter analysis: towards the definition of a lake-specific reference state. J. Paleolimnol. 44:963-978.

Mouthon J, 1996. Molluscs and biodegradable pollution in rivers: proposal for a scale of sensitivity of species. Hydrobiologia 317:221-229.

Mouthon J, 1999. Longitudinal organisation of the mollusc species in a theoretical French river. Hydrobiologia 390:117-128.

Mouthon J, Vilain R, 1990. [Les malacocénoses des sondages de Pluvis I et IV]. [Article in French]. In: J.L. Borel, J.P. Bravard and G. Montjuvent (eds.), Pluvis, lac disparu; du retrait glaciaire à l'aménagement hydroélectrique. Rev. Paleobiol. 22:41-45.

Mouthon J, Magny M, 2004. Malacological history of Lake Annecy (France): a comparison of Late Holocene (since 4700 BC) and present mollusc assemblages. Arch. Hydrobiol. 160:555-573.

Nevalainen L, Luoto T, 2012. Faunal (Chironomidae, Cladocera) responses to post-Little Ice Age climate warming in the high Austrian Alps. J. Paleolimnol. 48:711-724.

Oldfield F, Berthier F, 2001. The multi-proxy late-Pleistocene and Holocene record from the sediments of the Grand Lac d'Annecy, eastern France. J. Paleolimnol. 25:133-135.

Pereyra-Ramos E, 1981. The ecological role of Characeae in the lake littoral. Ekol. Pol.-Pol. J. Ecol. 29:167-209.

Renssen H, Seppä H, Heiri O, Roche DM, Goose H, Fichefet T, 2009. The spatial and temporal complexity of the Holocene thermal maximum. Nat. Geosci. 2:411-414.

Ricciardi A, Neves RJ, Rasmussen JB, 1998. Impending extinctions of North American freshwater mussels (Unionida) following the zebra mussel (Dreissena polymorpha) invasion. J. Anim. Ecol. 67:613-619.

Schloesser DW, Nalepa TF, 1994. Dramatic decline of unionid bivalves in offshore waters of western Lake Erie after infestation by the zebra mussels, Dreissena polymorpha. Can. J. Fish. Aquat. Sci. 51:2234-2242.

Strayer DL, 1999. Effects of alien species on freshwater mollusks in North America. J. N. Am. Benthol. Soc. 18:74-98.

Strayer DL, 2010. Alien species in fresh waters: ecological effects, interactions with other stressors, and prospects for the future. Freshwater Biol. 55:152-174.

Strayer DL, Malcom HM, 2007. Effects of zebra mussels (Dreissena polymorpha) on native bivalves: the beginning of the end or the end of the beginning? J. N. Am. Benthol. Soc. 26:111-122.

Van den Berg M, Coops H, Noordhuis R, Van Schie J, Simons 
J, 1997. Macroinvertebrate communities in relation to submerged vegetation in two Chara-dominated lakes. Hydrobiologia 342/343:143-150.

Vinçon-Leite B, Tassin B, Jacquet JM, 1995. Contribution of mathematical modeling to lake ecosystem understanding: Lake Bourget (Savoy, France). Hydrobiologia 300/301: 433-442.

Walker MJC, Griffiths HI, Ringwood V, Evans JG, 1993. An early-Holocene pollen, molluscan and ostracod sequence from Llangorse Lake, Powys, South Wales, U.K. Holocene 3:138-149.

Ward JM, Ricciardi A, 2007. Impacts of Dreissena polymorpha on benthic invertebrate communities: a meta-analysis. Divers. Distrib. 13:155-165.

Williams JW, Jackson ST, 2007. Novel climates, no-analog communities, and ecological surprises. Front. Ecol. Environ. 5:475-482.

Williamson C, Dodds W, Kratz T, Palmer M, 2008. Lakes and streams as sentinels of environmental change in terrestrial and atmospheric processes. Front. Ecol. Environ. 6:247-254.

Williamson C, Saros J, Vincent W, Smol J, 2009. Lakes and reservoirs as sentinels, integrators, and regulators of climate change. Limnol. Oceanogr. 54:2273-2282. 